\title{
The European External Action Service and Agenda- setting in European Foreign Policy
}

Citation for published version (APA):

Vanhoonacker - Kormoss, S., \& Pomorska, K. (2013). The European External Action Service and Agendasetting in European Foreign Policy. Journal of European Public Policy, 20(9), 1316-1331.

https://doi.org/10.1080/13501763.2012.758446

Document status and date:

Published: 01/01/2013

DOI:

10.1080/13501763.2012.758446

Document Version:

Publisher's PDF, also known as Version of record

Document license:

Taverne

Please check the document version of this publication:

- A submitted manuscript is the version of the article upon submission and before peer-review. There can be important differences between the submitted version and the official published version of record.

People interested in the research are advised to contact the author for the final version of the publication, or visit the DOI to the publisher's website.

- The final author version and the galley proof are versions of the publication after peer review.

- The final published version features the final layout of the paper including the volume, issue and page numbers.

Link to publication

\footnotetext{
General rights rights.

- You may freely distribute the URL identifying the publication in the public portal. please follow below link for the End User Agreement:

www.umlib.nl/taverne-license

Take down policy

If you believe that this document breaches copyright please contact us at:

repository@maastrichtuniversity.nl

providing details and we will investigate your claim.
}

Copyright and moral rights for the publications made accessible in the public portal are retained by the authors and/or other copyright owners and it is a condition of accessing publications that users recognise and abide by the legal requirements associated with these

- Users may download and print one copy of any publication from the public portal for the purpose of private study or research.

- You may not further distribute the material or use it for any profit-making activity or commercial gain

If the publication is distributed under the terms of Article $25 \mathrm{fa}$ of the Dutch Copyright Act, indicated by the "Taverne" license above, 


\section{Journal of European Public Policy}

\section{The European External Action Service and agenda- setting in European foreign policy}

\section{Sophie Vanhoonacker \& Karolina Pomorska}

To cite this article: Sophie Vanhoonacker \& Karolina Pomorska (2013) The European External Action Service and agenda-setting in European foreign policy, Journal of European Public Policy, 20:9, 1316-1331, DOI: 10.1080/13501763.2012.758446

To link to this article: https://doi.org/10.1080/13501763.2012.758446

曲 Published online: 08 Feb 2013.

Submit your article to this journal $\pi$

LII Article views: 13197

Q View related articles $\asymp$

Citing articles: 16 View citing articles 


\title{
The European External Action Service and agenda-setting in European foreign policy
}

\author{
Sophie Vanhoonacker and Karolina Pomorska
}

\begin{abstract}
The new High Representative of the Union for Foreign Affairs and Security Policy (HR) and the European External Action Service (EEAS) have emerged after the Lisbon Treaty as a potential driving force in European foreign policy. This article critically reviews the first two years of the existence of the EEAS to find out whether these new players have managed to shape the direction of the European Union's (EU) external activities. Building on a typology of agenda-setting strategies in the EU developed by Princen (2011), it successively examines how the HR and the EEAS have been trying to 'build credibility' and 'to gain attention' for their priorities. The empirical analysis shows that priority has been given to addressing the 'credibility challenge', with a particular emphasis on capacity-building. The strategies of mobilizing partners and arousing interest through framing still leave scope for improvement.
\end{abstract}

KEY WORDS Agenda-setting; European Foreign Policy; European External Action Service; High Representative.

\section{INTRODUCTION}

One of the distinguishing characteristics of the Common Foreign and Security Policy (CFSP) pre-Lisbon was that it was the member states, rather than the European Commission, acting as the motor of co-operation and integration. The national capitals wanted to keep a firm grip on the direction of foreign policy. In practice, the agenda was set by the six-monthly rotating Presidency. While having the advantage of bringing new impulses, the major flaw of the rotating chair system was lack of continuity and direction.

The Lisbon Treaty aimed to address the continuity and leadership problems by installing a longer-term chair both at the level of the European Council and the Foreign Affairs Council (FAC). The latter is the dual-hatted High Representative of the Union for Foreign Affairs and Security Policy, who besides chairing the FAC is also Vice-President of the European Commission. She is assisted by her own foreign policy administration, the EEAS. Like the member states, the HR has the right to put forward foreign policy proposals. 
This article addresses the question of how the post-Lisbon institutional structure has affected the process of agenda-setting and to what extent the HR and her staff have taken over from the rotating Presidency as an engine behind initiatives in European foreign policy. The main focus is not on questions of strategic direction, formally decided at the highest level of the European Council, but on the so-called 'decision agenda' of the FAC and its underlying bureaucracies. Rather than the long-term structural questions, these are the issues on which a concrete decision can be taken (Kingdon 1994).

Following an introductory section on agenda-setting in foreign policy more broadly, we successively examine the formal and informal practices preLisbon and present the main changes introduced by the new Treaty. Secondly, building on a typology of agenda-setting strategies in the EU developed by Princen (2011), we examine how, in the first two and a half years of Ashton's office (2010-June 2012), the HR and the Brussels-based EEAS have been building capacity, claiming authority, mobilizing support, and arousing interest. ${ }^{1}$ Although we will also make reference to the 140 Union delegations as an important pillar of the EEAS, their role in the agenda-setting process is outside the scope of this article.

\section{AGENDA-SETTING IN FOREIGN POLICY}

Agenda setting is the first and indispensable phase in any policy-making process. While some issues may emerge automatically consequent to prior commitments, many others never materialize, or only appear after a lengthy process of trial and error. In his seminal work on 'Agendas, alternatives and public policies', Kingdon (1994) has pointed to the key role of policy entrepreneurs able to couple policy proposals to emerging problems and take advantage of a positive political mood. He defined them as 'advocates who are willing to invest their resources - time, energy, reputation, money - to promote a position in return for anticipated future gain in the form of material, purposive, or solidary benefits (Kingdon 1994: 179).

There is not much literature specifically focusing on agenda-setting in foreign policy. The few existing studies mainly focus on the United States (US), looking into the role of the president (e.g., Birkland 1997; Wood and Peake 1998). Tallberg's study on the agenda-shaping powers of the Council Presidency in the EU context includes foreign policy examples but is much broader in scope (Tallberg 2003). As already stated by Wood and Peake (1998: 173), 'foreign policy does not readily fit the theoretical mold most scholars associate with domestic issues'. Although many concepts and mechanisms developed to get a better insight in public policy-making are relevant, there are also peculiarities to be taken into account. While the role of policy entrepreneurs in foreign policy is also crucial, the agenda is set to a large extend by crisis events, or what Kingdon (1994) calls 'focusing events'. The fall of a regime, a terrorist attack and human rights violations all require a prompt response and impose themselves on the agenda, often surpassing 
other issues that work their way up (Princen and Rhinard 2006). In such cases, issues often arise much more quickly than in other policy sectors. Another difference is that the policy-making process is much more insulated or even lacking transparency, with governments trying to sideline parliaments. Although advocacy groups also matter in foreign policy, their roles differ widely and takes a broad variety of forms such as third states and international organizations, or non-governmental organizations (NGOs) with a particular foreign policy agenda (e.g. Joachim and Dembinski 2011). For a majority of the larger public, foreign policy tends to be of remote interest, but in highly salient issues such as situations of mass starvation and emerging wars it can be an important force for new policies.

In their search for a better grasp of the factors contributing to issues acquiring agenda status, scholars have identified a variety of strategies such as venue shopping and framing (e.g. Baumgartner and Jones 1991; Cobb et al. 1976; Princen 2011; Schattenschneider 1960). When venue shopping, strategic players try to identify the venue that offers them the best chances to advance their goals. In a system of multilevel governance such as in the EU, the potential number of venues is considerable, triggering Peters (2001: 88) to call it an 'agendasetting paradise'. This approach has to be nuanced in the intergovernmental area of CFSP, where the principal decision-maker continues to be the Council. The importance of framing in the construction of new agenda issues is well known. By emphasizing certain values and facts, policy entrepreneurs will search to attract attention and try to induce their audience to look at issues from their preferred perspective. In the field of foreign policy, it makes a big difference whether an issue is framed in security, diplomacy or development terms. The choice of the wording will not only affect the venue where the issue will be discussed, it will also have important implications for the instruments used to address the problem.

In this research we make use of a typology of agenda-setting strategies in EU policy-processes developed by Princen (2011), but also identified in earlier analyses of Council Presidencies conducted by Tallberg (2003,2004), and recently applied by Stephenson (2012) in the transport field. Starting from the assumption that agenda-setters face the two main challenges of 'gaining attention' and 'building credibility', and can potentially affect both venues and frames, Princen (2011) has developed a typology of four strategies: mobilizing support; arousing interest; claiming authority; and building capacity. Below we briefly describe the different categories, translating them to the field of foreign policy and illustrating them with European foreign policy examples.

\section{Gaining attention}

A key challenge for any policy entrepreneur aiming to put an issue on the agenda is to gain attention for it. The two main strategies concern the control of participation (mobilizing support) and the framing of the topic (arousing interest). 
(a) Mobilizing Support is all about the involvement and exclusion of different actors. This may be attempted through various strategies, including horizontal (between different EU bodies) and vertical venue shopping. Given the sensitive character of European foreign policy and the central role of the Council, horizontal venue shopping is generally more difficult here than in other policy areas, but it is not impossible. For example, by mobilizing 'development policy-makers', an issue will be subject to a different decision-making procedure than when discussed as an intergovernmental CFSP matter. Players can also shop between vertical levels of decisionmaking, i.e., the national, EU and international level - such as the United Nations (UN), North Atlantic Treaty Organization (NATO) or the Organization for Security and Co-operation in Europe (OSCE).

(b) Arousing interest. The success in mobilizing supporters often depends on the way a problem is defined and framed. Interest in the issue can be aroused either by using 'big words' or by a small-step approach. In the first case, agenda-setters may try to link a foreign issue to a big moral cause or to the EU's long tradition as a soft power, strong in the promotion of human rights and multilateral solutions. The small-step approach is more time-consuming and tends to focus on the more detailed and technical aspects of a dossier. It makes use of a variety of instruments such as the presentation of studies, the organization of conferences and field trips (e.g., for Political and Security Committee [PSC] Ambassadors) to draw the attention to a particular issue.

\section{Building credibility}

Given the parallel existence of several venues to discuss foreign policy issues, it is important that the proposed venue is credible both in terms of organizational capacity as well as in terms of legal competencies and expertise.

(a) Building Capacity. A key condition in becoming accepted as an actor in a particular domain is possession of the required organizational capacities. In foreign policy, EU member states have been reticent to equip 'Brussels' with the required bureaucratic resources and have been managing policy co-operation through the national capitals. The establishment of the EEAS is therefore a significant milestone. The literature also includes the mobilization of capacities of outside players as being part of the capacitybuilding exercise.

(b) Claiming authority. Building credibility may involve framing an issue in EU terms, i.e., justifying why it should be dealt with at the EU level. Important sources of authority are not only the legal competencies of an actor but also their expertise in a particular issue. In a complex institutional arena such as the EU, it is not only important to possess content expertise but also to have staff with a good understanding of the relevant procedures and developed negotiation skills. 


\section{AGENDA-SETTING IN CFSP}

For most of its history, the process of foreign policy initiation has been ad hoc. As there was no general agreement on a strategic agenda, rotating Presidencies were tempted to $(\mathrm{ab})$ use their period in the chair to get on their national hobbyhorses. Once their term was over, there was often no follow-up. The European Commission, which could have functioned as a source of continuity, was careful not to step on member states' toes and was reticent to use its right of policy initiative (Nuttall 2000). The Amsterdam Treaty (1999) brought foreign policy entrepreneurship from an unexpected corner. Formally, the new High Representative for CFSP, based at the Council General Secretariat, did not have an autonomous role. The first occupant of the position, the highly experienced former Spanish foreign minister Solana (1999-2009), managed to gain the trust of the national capitals and succeeded in carving out a political role for himself and informally affecting the agenda-setting process (Dijkstra 2012; Spence 2006).

The Lisbon Treaty considerably strengthened the potential role of the High Representative as foreign policy entrepreneur. Formally, the HR is now an autonomous player who can submit proposals and fulfil an implementing and representational role. In the area of CFSP, she shares the right to put forward proposals with the member states (Art. 30.1, TEU). In the other areas of EU external action, she can submit joint proposals together with the European Commission (Art.22.2, TEU).

Having the formal right of initiative is an important asset but not a guarantee of successful policy initiation. This also depends on other factors, such as institutional rules, and the preferences and eagerness of other players to reach an agreement (Pollack 1997). The policy-making rules in CFSP, where decisions are adopted by unanimous consensus, are definitely a constraining factor for any agenda-setter. This does not mean that the de facto agenda-setting role of the $\mathrm{HR}$ is condemned to be minimal. There are at least three factors that give her some scope for having an impact. The new incumbent has a potentially very powerful source of information and expertise at her disposal - her own foreign policy administration. Besides the Brussels-based EEAS, this includes the 140 EU delegations all over the world, regularly reporting developments in third countries and international organizations such as the United Nations (Drieskens 2012). Secondly, as chair of CFSP working groups, the Political and Security Committee (PSC) and the Council, Ashton and her staff are in a privileged position to put new issues on the table and to steer discussions. They also have the advantage that they occupy long-term positions. Already in mid-2012, the HR was among those who had the longest experience at the FAC table. A final factor is the 'crisis-like' character of CFSP. Crisis situations require a quick response and limited time horizons to reach an agreement may be to the advantage of the chair.

The remainder of this article examines whether and how the HR and her staff have been giving shape to their new agenda-setting role. In line with the model 
Table 1 Agenda-setting strategies in the EU

\begin{tabular}{lll}
\hline Challenges & Venue strategies & Framing strategies \\
\hline Building credibility & Capacity-building & Claiming authority \\
Gaining attention & Mobilizing supporters & Arousing interest \\
\hline
\end{tabular}

Source: Adapted from Princen (2011).

introduced earlier, we show how Catherine Ashton and the EEAS have tried to build up credibility and gain attention in a variety of different foreign policy issues. Since the HR was new in her position and still had to build up her service, we start with the challenge of building credibility and the strategies of capacity-building and claiming authority. As a next step we look at how Ashton and the EEAS have tried to gain attention for particular foreign policy issues by mobilizing supporters and arousing interest.

\section{BUILDING CREDIBILITY}

Building credibility is a challenge for any player engaging in policy initiation. In the case of Ashton and the EEAS, the challenge was particularly demanding. As newcomers, they could only partially fall back on earlier established practices and procedures. The next section examines which strategies they have been using in building up capacities and claiming authority.

\section{Capacity-building}

The effectiveness of any political actor in achieving their priorities depends as much on their personal qualities as on the strength of the administrative resources available to them. It is therefore not surprising that Ashton considered the set-up of the external service as 'a top priority and not just a bureaucratic exercise'2 $^{2}$ (EP hearing, 11 January 2010). To this end she devoted a big part of her first six months in office, negotiating over the shape of the new service with member states, the EP and the European Commission. By June the different institutions had reached the general agreement that led to a Council framework decision outlining the EEAS organizational structure (Council Decision 2010). Following a deal on the budget and financial and staff regulations, the EEAS was officially launched in December 2010. The negotiation process was not always easy, but overall the first phase of creating the new body went relatively smoothly, thanks largely to Ashton's strong negotiation skills and determination (Christoffersen 2011; Howorth 2011).

The Treaty foresaw that the EEAS staff would be drawn from civil servants of the European Commission, the Council Secretariat and national diplomats. The first two groups, transferred en masse in December 2010 from DG Relex (585 officials) and from parts of Directorate-General (DG) Development (93 
officials) of the European Commission and DG External and Politico-Military Affairs of the Council Secretariat (411 officials). They joined the service immediately in January 2010, while the third category of national diplomats was employed through a huge recruitment round (Hemra et al. 2011). This process turned out to be rather problematic, partly because capitals fiercely lobbied for catapulting their nationals into senior positions, but also because nominations were delayed owing to the HR's micromanagement (Interview no. 4). In their non-paper to Ashton (December 2011), 12 ministers of foreign affairs urgently pleaded with the HR to streamline these procedures. An additional challenge has been the unwillingness of member states to commit more financial resources to the service and keeping it 'budget neutral'.

Besides the Brussels-based diplomatic corps, the HR can also fall back on the work and expertise of the European Union delegations, potentially a tremendous source of information gathering and processing, independent of the member states. These former Commission delegations to third countries and international organizations were expanded with staff from the Council Secretariat and national diplomats (Drieskens 2012). In several cases, however, the staff of the EEAS is only limited to one (Hemra et al. 2011) and it will still take time before the delegations will have adapted to their new political duties both in terms of resources and expertise (Duke et al. 2012).

Setting up the EEAS has been consuming much of the energy of the HR and her cabinet in their first year in office. It was an indispensable condition for her development into a foreign policy entrepreneur. However, solely the creation of an organizational structure and its staffing is not sufficient for this development. The next section examines to what extent the HR and the EEAS have succeeded in being recognized as authoritative sources of foreign policy.

\section{Claiming authority}

The Lisbon Treaty makes Brussels a key locus of European diplomatic action and gives the HR a central place in all phases of the policy cycle. She is an autonomous player ${ }^{3}$ who is explicitly encouraged to contribute to CFSP with own proposals. The Treaty on European Union refers to this new competence on four different occasions (Art. 18, Art.22, Art. 27 and Art. 30).

Legal competencies are, however, only part of the story. A further important source of authority is expertise. When assuming her position, the HR had little foreign policy experience. Her difficult start in the job quickly showed that her experience as former Commissioner for Trade was not enough to compensate for a lack of diplomatic know-how. This was illustrated by her rather poor performance during the confirmation hearing before the European Parliament in January 2010 (Vogel 2010) and several misjudgements in setting priorities in the first months (Howorth 2011). ${ }^{4}$ In spite of this, she chose to staff her private office with trade experts from her cabinet as Trade Commissioner rather than with experienced and well-connected senior diplomats. 
The lack of personal expertise made it all the more important to give top priority to the build-up of the EEAS and in her first report on the EEAS (High Representative 2011), Ashton refers to its establishment as a milestone. On paper, the global coverage of the delegations and the bringing together of both European civil servants and national diplomats has a huge potential. In practice, though, there is still much scope for progress and learning, both in terms of content and process expertise (Beach 2005). The previously mentioned non-paper on the EEAS by 12 ministers of foreign affairs is revealing in this respect (Non-paper 2011). It asks for additional, timelier preparatory policy and decision-making papers and encourages the service to further develop internal manuals and guidelines. The interviews echoed the need for higher quality written work and more professionalism (Interviews 5, 6, 7, 8). National diplomats have been repeatedly complaining about last-minute changes to the PSC agenda and problems with the timely circulation of documents, including even draft Council Conclusions (Interviews 7, 8, 12). Interviewees, both in the member states and in the EEAS, have referred to lack of entrepreneurial thinking and a proactive attitude not only by geographical desk-officers, but also at the level of senior management (Interview 5).

Several issues play a role here. Firstly, it has to be taken into account that many of the former staff of DG Relex and the Council General Secretariat are not professional diplomats. Former Commission officials have very sound knowledge on both the geographical areas and horizontal themes, but typically have been operating mostly as project managers. Staff coming from the national diplomatic services may be highly skilled diplomats but may not always have experience in Brussels (Spence 2012). While it is clear that the different groups have plenty to learn from each other, the divergences in knowledge and expertise have further complicated the daily management of EU foreign affairs.

Secondly, the EEAS does not yet have a single institutional memory at its disposal. Different players come with divergent working methods. Rules and procedures are developed as problems present themselves. Last but not least, the new service brings together people from different epistemic communities - each with their own mind-set (Spence 2012). For example, the hierarchical culture of Commission officials has been clashing with the more horizontal work culture of some of the national diplomats (Interview 1). More fundamentally, it cannot be taken for granted that the different components of the EEAS have convergent views about diplomacy and Europe's future role in international relations (for more on this, see Juncos and Pomorska 2013).

\section{STRATEGIES FOR GAINING ATTENTION}

Since the foreign policy agenda is largely 'event-led', many issues compete for the attention of policy-makers. In this section we look at how Ashton and the EEAS have been mobilizing supporters and arousing interest for particular foreign policy issues. 


\section{Mobilizing supporters}

Effective agenda-setting is linked to mobilizing supporters, both in the EU and outside. Here, we focus on the internal supporters within the EU. Since unanimity is still the prevalent decision-making rule in CFSP, alliance-building with the member states and the European Commission is indispensable.

Ashton's dual-hatted position makes the European Commission a natural ally. After the transfer of DG Relex and a large part of DG Development to the EEAS, the Commission decided to stay involved in the works of the PSC. ${ }^{5}$ The two have already written a joint communication on the Southern Mediterranean (European Commission and High Representative 2011) and are obliged to prepare joint proposals in the case of sanctions. The EEAS is bound by the Treaty to respect the normal Commission procedure every time the HR acts in her capacities as Commission Vice-President (Art 18.4 TEU), i.e., with regard to external relations, excluding CFSP issues. The Commission has made it clear, e.g., in its 'Vademecum on working relations with the European External Action Service' (European Commission 2011), that on those occasions all initiatives of the EEAS need to be prepared in co-operation with the relevant Commission services and must go through the inter-service consultation procedure. The sensitivity and complexity of the relationship is exemplified by the fact that it took one year to negotiate the practical guide on their mutual interaction (European Commission 2012).

The abovementioned consultation practice is already in place and the EEAS is fully included in the inter-service consultation tool, CIS-net. The scope for the EEAS to act in its capacity as support for the HR as a Vice-President for the Commission, is a large part of its activities and includes Partnership and Co-operation Agreements (PCAs) and country papers. The EEAS also occasionally acts as a supporting service to different DGs in the Commission, for instance to the Commissioner responsible for the European Neighbourhood Policy regarding policy matters or to DG Development and Cooperation (DEVCO) for the strategic and multi-annual programming cycle (European Commission, 2011: 11-12).

The interviewed officials from the Commission insist that while the everyday co-operation at the desk officer level is mostly smooth, higher-level relationships of co-operation are more troubled (Interviews 9 and 12). The HR was supposed to chair the meetings of the External Relations Group of Commissioners, but after her repeated absence this role was taken over by the Commission President. The interviewees also mentioned that the agenda management by the EEAS is still weak and that dossiers, even those that have been through the inter-service consultation procedures, tend to 'get lost' in the highest levels of the EEAS hierarchy. Some see the process as being slowed down by Ashton's insistence on controlling the dossiers. Others point to the inability of the HR cabinet to deal with dossiers effectively.

The relations with the member states are still tense overall. There are continuous complaints about the late delivery of agendas and documents (Interviews 6, $7,8,9,11,12)$. National diplomats point out that often the discussions in the 
PSC are rather shallow, as the Ambassadors are simply not given enough time to consult with their capitals (Interviews 7,8). The member states also complain about the lack of interest on the part of the HR in the Common Security and Defence Policy (CSDP) (see below). On the other hand, EEAS officials complain that member states often push for their 'pet' issues when choices have to be made. There is a lot of informal lobbying, also at the level of the HR and her cabinet. Recently, several member states have used the 'Any Other Business' (AOB) agenda item in order to raise issues. On the positive side, the EEAS officials interviewed reported that some foreign ministers, e.g., from Belgium and Sweden, asked the HR for briefing before their trips to third countries or enquired whether there was any message they could deliver in the name of the EU. An overall good atmosphere was also reported at the FAC meetings, which is not always the case in preparatory bodies such as the Committee of Permanent Representatives (COREPER II) or the PSC.

Even though the HR and the EEAS took over most of the duties of the rotating Presidency in external relations, the Presidency continues to be an important partner for several reasons. Firstly, it still chairs COREPER II, which as the 'mother of all committees' prepares the agenda and the draft conclusions for the FAC. There are many cross-cutting issues, such as sanctions, where co-ordination is simply indispensable. Secondly, the country holding the Presidency is an information hub and has a good overview of the member states' positions in many of the dossiers. Finally, they have a designated budget for their time in office and can support the EEAS, for example by replacing them at various meetings (bilateral summits, meetings in the European Parliament or trips to third countries).

The Presidencies themselves employ different strategies of dealing with the EEAS. The Belgians (second half of 2010) and the Hungarians (first half of 2011) were rather withdrawn and had decided to remain in the shadow of the Service. The Hungarian Presidency even rejected the EEAS pledge to chair the meetings in the Council, until the EEAS would appoint their own officials to take over. Still, no matter what the strategy, each Presidency has its own priorities in external relations and lobbies the EEAS for putting them on the agenda. Hungary, for example, prioritized the relationship with the Western Balkans and the organization of the Western Balkan Forum. Despite the HR's initial lack of enthusiasm, the event took place in June 2010 in Luxembourg (Interviews 6 and 7). The Polish Presidency was more proactive and vocal in expressing its political agenda. They put a heavy emphasis on the Eastern Partnership and its summit in Warsaw in September 2010. The EEAS expressed its objections and tried (unsuccessfully) to prevent the traditional PSC trip planned by the Polish Presidency to Moldova and Ukraine (Interview 8), a move that can be considered an attempt to set the agenda.

As for the other member states, the biggest players are traditionally more engaged, especially the United Kingdom and France, also sitting at the UN Security Council. The Middle East Peace Process and Iran are by now typical issues that are prioritized by the HR and where there is close co-ordination 
with the bigger member states. At the same time the interviewees have referred to an ongoing power struggle. Each member state tries to influence the agenda so that it mirrors their concerns. In June 2012, the United Kingdom (UK) insisted on including Pakistan among the discussion points at the FAC and even lobbied for Council Conclusions on this topic, something the HR and the EEAS were not prepared to agree on easily. France had pushed for a greater interest in the Sahel, while countries like the UK and Denmark have been active in drawing attention to anti-piracy measures. Other countries also have chances of putting items on the agenda. In July 2012, Poland raised a point that was immediately accepted by the EEAS, namely that the situation in Lebanon should be put on the PSC agenda. While this attitude is appreciated by member states, they also point out that the Service should be more proactive.

In sum, there is definitely room for improvement in the process of mobilizing supporters as a step towards effective agenda-setting. While co-operation with the Presidencies so far has been rather good, relations with the European Commission, especially at the higher levels of the hierarchy, could benefit from more attention and co-operation. In the Council, it is in the first place the member states mobilizing the HR and the EEAS for their own priorities and preferences rather than vice versa.

\section{Arousing interest}

A second way for the HR and the EEAS to gain attention is by linking EU action to broader international objectives or to particular strengths of the EU as an external actor. When assuming her position, Catherine Ashton could depart from an already well-established narrative. The EU's documents often portray the Union as an example of successful international co-operation and as a soft or normative power, exerting influence through co-operation rather than coercion (Council of the EU 2003; Manners 2010).

From the start of her tenure, the HR strongly tied in with this vision of the $\mathrm{EU}$ as a 'civilizing force'. Already in her hearing before the EP in January 2010, she referred to the EU's engagement 'to promote peace, to protect the vulnerable, to fight poverty and to address the many challenges of our time'. ${ }^{6}$ In a speech at Corvinus University in Budapest in February 2011, she described the EU as 'a soft power with a hard edge - more than the power to set an example and to promote its values. But less than the power to impose its will' (Ashton 2011). Further important dimensions of her narrative are globalization and the rise of new powers. She argued that both developments ask for more unity amongst the member states and more integrated strategies, two requirements for which the HR and her service are well-equipped to contribute (see, for example, her speech at the Athens Concert Hall, July 2010).?

Besides embedding her role in the broader frame of EU external action, Ashton also used her first year in office to convince the member states of the importance of specific priorities such as the policy towards EU's neighbours and the development of the strategic partnerships (ibid.). The message seems 
to have gotten across, since all interviewees at COREPER, the PSC and the Commission were well aware of these priority fields.

It remains to be asked to what extent Ashton has been able to act as a driving force in arousing interest in the above-mentioned areas. The balance sheet is rather mixed. In the period between 2010 and mid-2012, relations with the neighbours were indeed heavily debated, but this was owing to the Arab Spring rather than to Ashton's capacity to set the tone. Although the 'jasmine revolutions' were ideal focusing events for the HR and her service to assert themselves, they initially remained passive. The HR was amongst the last to visit Tunis and was 'painfully slow' in responding to the events in Egypt (e.g. Erlanger 2011). Rather than taking the lead, she waited for a mandate of the 27 member states. Similarly, in the case of Libya, the tone was set by the big member states, provoking Howorth (2011: 320) to conclude that 'she was, in many ways, instrumental in ensuring that ... the EU took a backseat to its own Member States, to the US and NATO'. The most positive example from the neighbourhood, where the HR and her staff were able to play a proactive role, is the Western Balkans. Together with a small team around EEAS senior counsellor Robert Cooper, Ashton managed to play a substantial role in easing tensions between Kosovo and Serbia and in forging an agreement on integrated border management and Kosovo regional representation (Interview 3).

Ashton's efforts to arouse interest in strategic partnerships, her other priority, has been limited. Her input into the special European Council (October 2010) on relations with the strategic partners was disappointing, leading the Belgian Presidency and the cabinet of Van Rompuy to step into the vacuum (Interview 4). This mode has continued after the summit, and no further major initiatives have been taken since.

The dossiers that the HR has attempted to keep off the policy agenda are as important as the dossiers for which she has tried to arouse interest. Observers unanimously point to crisis management as the case in point (Interviews 2, 3). While under Solana more than 20 civilian and military missions were launched (2003-2009), the role of the EU as a crisis manager has almost come to a standstill. No major new missions have been launched and the HR shows very little interest in the existing missions. According to observers, this has to do with a lack of personal interest as well as with her British background. The establishment of a Brussels-based EU-Civil-Military Operations Centre for the Horn of Africa, for example, only came after heavy pressure from the Polish Presidency and from France (Pomorska and Vanhoonacker 2012). Although this is a negative example, it shows how the HR and EEAS are in a powerful position to steer debates and lay particular accents on the development of CFSP.

This brief overview shows that Ashton has very much embedded her European foreign policy discourse in the traditional narrative of Europe as a 'soft power', with a special emphasis on the neighbourhood and the strategic partnerships. While the latter topic has not yet received much attention, relations with the Mediterranean borderlands have been omnipresent. However, this is less the product of a well-developed strategy than of the 
unexpected revolutionary events in the region. Despite the receptive political climate and the general recognition that EU action was required, Ashton and her staff shied away from a proactive approach, preferring to wait for a mandate from the member states.

\section{CONCLUSION}

By giving the HR and her staff the formal right to put forward policy proposals, the Lisbon Treaty has, at least on paper, created a potentially important new foreign policy entrepreneur. Being an influential agenda-setter, however, does not come automatically. It requires skilful use of a repertoire of different strategies both in terms of venues and framing. Applying a model by Princen (2011) on agenda strategies in the EU and taking into account the particularities of European foreign policy, this article has explored the strategies used by the new EU foreign policy chief and her staff to build credibility and gain attention.

Of all four strategies, the HR has undoubtedly invested the most in capacitybuilding. This is not a surprise, since the new diplomatic service had to be established from scratch and a well-equipped organization was imperative to become operational. Ashton proved to be a skilful negotiator, and despite the diverging views amongst the parties involved she managed to get the service off the ground within the first year of her appointment. However, the recruitment of national diplomats, understaffing and budgetary capacity remain important challenges.

The second strategy of claiming authority has proved more difficult. Although the Treaty gives her important powers in terms of agenda-setting, the new HR clearly suffered from her lack of foreign policy expertise. Especially in her first year in office, there were several gaffes and misjudgements, leading some observers to wonder whether she was up to the job. In addition, she was criticized for not being forceful enough vis-à-vis dissenting member states. Unfortunately, the personal deficiencies of the HR were only partly compensated by the new service. A tremendous source of both content and process expertise, the EEAS suffered from the diverse professional backgrounds of its members, the absence of standard operating procedures, and the lack of an esprit de corps.

Successful agenda-setters rarely have the luxury to act on their own. They have to mobilize allies and sideline opponents. Given the HR's dual-hatted role, the European Commission is a natural partner. At lower levels the co-operation is taking shape well, but higher in the hierarchy it continues to be rather problematic. Relations with the member states vary but tend to be competitive. National capitals have not lost their old habits of getting on their particular hobbyhorses. However, since the formal agenda of meetings is drafted by the EEAS, it is in a powerful position to resist demands and it does so regularly. A clear example is CSDP, where the HR, to the frustration of many, has managed to keep a minimal agenda. Overall, the rotating chair remains a privileged partner of co-operation, as it continues to chair COREPER II and replaces the HR if she is not available. If the priorities of the rotating chair and the 
HR coincide, they can be a powerful alliance. If not, as was the case of the Polish Presidency pushing for further steps in CSDP, this can lead to power struggles.

Finally, we looked at how the HR and the EEAS have tried to raise interest. Ashton has not shunned away from situating her role in that of the broader context of the EU as a soft power and the rapidly changing international context of emerging new powers. She has also managed to clearly articulate her foreign policy priorities of establishing the EEAS, fostering close relations with the EU's neighbourhood and strategic partnerships. The way these priorities have been followed-up by both the HR and the EEAS, however, has been unconvincing.

In contrast to the sometimes extremely negative reviews in the press, our balance sheet is more nuanced. Overall, the strategies aimed at building credibility have been most developed. Given the fact that we look at the agendasetting role of a new player, this should not come as a surprise. Neither should we be amazed that this process was full of hurdles. Overcoming some of them, like the development of an EEAS esprit de corps, may be only a question of time, but others, such as the lack of budget and understaffing, may be more structural, especially in a period of financial crisis. The strategies aimed at gaining attention, have proven more difficult to materialize. The HR and the EEAS have been more preoccupied with internal problems than with investing efforts in mobilizing possible partners and thinking in terms of framing particular foreign policy issues. This choice can be understood in the light of the recent character of the EU's diplomatic system, but if these players want to develop into fully fledged foreign policy entrepreneurs they will have to give absolute priority to further investment into these strategies.

Biographical notes: Sophie Vanhoonacker has a Chair in Administrative Governance and is Jean Monnet Professor at Maastricht University, the Netherlands. Karolina Pomorska is a Marie Curie Fellow at the Department of Politics and International Studies, University of Cambridge. She is currently on leave from Maastricht University, The Netherlands, where she is an Assistant Professor.

Address for Correspondence: Sophie Vanhoonacker, Faculty of Arts and Social Sciences, PO Box 616, NL-6200 MD Maastricht. email: s.vanhoonacker@ maastrichtuniversity.nl/Karolina Pomorska, Department of Politics and International Studies, University of Cambridge, Alison Richard Building, 7 West Road, Cambridge, CB3 9DT, United Kingdom. email: kp377@cam.ac.uk

\section{NOTES}

1 The authors used secondary literature, documentary analysis and empirical evidence obtained from twelve semi-structured interviews with 14 officials, conducted in Brussels at the end of 2011 and in 2012. The officials were based in the EEAS, in national Permanent Representations to the European Union and in the European Commission. All interviews were coded and are anonymous.

2 For a verbatim report of the hearing on 11 January 2010, see http://www.europarl. europa.eu/hearings/static/commissioners/cre/ashton.pdf, accessed 2 June 2012. 
3 Here, we refer to the formal arrangements as envisaged by the Treaty and the legal right of the HR to propose actions. However, as will be shown later in the article, in practice the role of HR is not as autonomous as it could be derived from the Treaty text and the HR's power to launch initiatives and implement policies is shared with the Commission and the member states.

4 To give three examples, she was criticized for not flying to Haiti after the earthquake (January 2010); for visiting Ukraine instead of attending an informal meeting of EU defence ministers (February 2010); and for missing the EU-Morocco summit in Granada.

5 The F3 Unit in the Secretariat General of the Commission hosts the PSC Representative and the Commission's member of the Nicolaides group.

6 See http://www.europarl.europa.eu/hearings/static/commissioners/cre/ashton.pdf, accessed 2 June 2012.

7 See http://www.nieuwsbank.nl/en/2010/07/11/H002.htm, accessed 2 June 2012.

\section{REFERENCES}

Ashton, C. (2011). 'A world built on co-operation, sovereignty, democracy and stability'. Speech given at Corvinus University Budapest, 25 February, 2011, available at http://europa.eu/rapid/pressReleasesAction.do?reference=SPEECH/11/126, accessed 4 June 2012.

Baumgartner, F. and Jones, B. (1991) 'Agenda dynamics and policy subsystems', Journal of Politics 53(4): 1044-74.

Beach, D. (2005) The Dynamics of European Integration: Why and When Institutions Matter, Basingstoke: Palgrave Macmillan.

Birkland, T.A. (1997) After Disaster: Agenda Setting, Public Policy and Focusing Events, Washington, DC: Georgetown University Press.

Christoffersen, P. (2011). 'The creation of the European External Action Service'. Lecture given at Maastricht University, 17 February, available at: http://www. mceg-maastricht.eu/publications.html, accessed 4 June 2012.

Cobb, R., Ross, J. and Ross, M. (1976) 'Agenda building as a comparative political process', American Political Science Review 70(1): 126-38.

Council of the EU (2003) 'A secure Europe in a better world', European Security Strategy, Brussels, 12 December 2003

Council of the EU (2010) 'Council decision of 26 July 2010 establishing the organization and functioning of the European External Action Service', 2010/427/EU, 2010, OJ L201/30-40

Dijkstra, H. (2012) 'Agenda-setting in the Common Security and Defence Policy: an institutionalist perspective', Cooperation and Conflict 47(4): 454-72.

Drieskens, E. (2012) 'What's in a name? Challenges to the creation of EU delegations', The Hague Journal of Diplomacy 7(1): 51-64.

Duke, S., Pomorska, K. and Vanhoonacker, S. (2012) 'The EU's diplomatic architecture: the mid-term challenge', European Diplomacy Policy Papers, Paper No.10, available at http://dseu.lboro.ac.uk/publications/policypapers.html, accessed 2 June 2012.

European Commission (2012) 'Working arrangements between Commission and the European External Action Service (EEAS) in relation to external relations issues', 13 January 2012, SEC(2012)48.

European Commission (2011) 'Vademecum on working relations with the European External Action Service (EEAS)', SEC(2011)1636.

European Commission and High Representative (2011) 'Joint communication to the European Council, the European Parliament, the Council, the ECOSOC and the Committee of the Regions on a partnership for democracy and shared prosperity with Southern Mediterranean', 8 March 2011, COM(2011)200 final. 
Hemra, S., Raines, T. and Whitman, R. (2011) 'A diplomatic entrepreneur. Making the most of the European External Action Service', London: The Royal Institute of International Affairs.

High Representative (2011) 'Report by the High Representative to the European Parliament, the Council and the Commission', 22 December, available at http://www.eeas. europa.eu/top_stories/2012/050112_eeas_report_en.htm, accessed 2 June 2012.

Howorth, J. (2011) 'The "new faces" of Lisbon: assessing the performance of Catherine Ashton and Herman van Rompuy on the global stage', European Foreign Affairs Review 16: 303-23.

Joachim, J. and Dembinski, M. (2011) 'A contradiction in terms? NGOs, democracy, and European foreign and security policy', Journal of European Public Policy 18(8): $1151-68$.

Juncos, A.E. and Pomorska, K. (2013). "'In the face of adversity": explaining the attitudes of EEAS officials vis-à-vis the new system', Journal of European Public Policy, doi: 10.1080/13501763.2012.758451.

Kingdon, J.W. (1994) Agendas, Alternatives, and Public Policies, New York: Longman.

Manners, I. (2010) 'Global Europa: mythology of the European Union in world politics', Journal of Common Market Studies 48(1): 67-87.

'Non-paper on the European External Action Service from the foreign ministers of Belgium, Estonia, Finland, France, Germany, Italy, Latvia, Lithuania, Luxembourg, The Netherlands, Poland and Sweden', 8 December 2011, available at http:// www.europarl.europa.eu/meetdocs/2009_2014/documents/afet/dv/201/201203/ 20120321_nonpaperfms_en.pdf

Nuttall, S. (2000) European Foreign Policy, Oxford: Oxford University Press.

Peters, G. (2001) 'Agenda-setting in the European Union', in J. Richardson (ed.), European Union: Power and Policymaking, London: Routledge, pp. 77-94.

Pollack, M. (1997) 'Delegation, agency, and agenda-setting in the European Community', International Organization 51(1): 99-134.

Pomorska, K. and Vanhoonacker, S. (2012) 'Poland in the driving seat: a mature Presidency in turbulent times', Journal of Common Market Studies 50(Annual Review): 576-84.

Princen, S. (2011) 'Agenda-setting strategies in EU policy processes', Journal of European Public Policy 18(7): 927-43.

Princen, S. and Rhinard, M. (2006) 'Crashing and creeping: agenda-setting dynamics in the European Union', Journal of European Public Policy 13(7): 119-32.

Schattschneider, E. (1960) The Semisovereign People: A Realist's View of Democracy in America, New York: Holt, Rinehart and Winston.

Spence, D. (2006) 'The Commission and the Common Foreign and Security Policy', in D. Edwards with G. Spence (eds), The European Commission, London: John Harper, pp. 356-95.

Spence, D. (2012) 'The early days of the European External Action Service: a practitioner's view', The Hague Journal of Diplomacy 7(1): 115-34.

Stephenson, P.J. (2012) 'Image and venue as factors mediating latent spillover pressure for agenda-setting change', Journal of European Public Policy 19(6): 896-916.

Tallberg, J. (2003) 'The agenda-shaping powers of the EU Council Presidency', Journal of European Public Policy 10(1): 1-19.

Tallberg, J. (2004) 'The power of the Presidency: brokerage, efficiency and distribution in EU negotiations', Journal of Common Market Studies 42(5): 999-1022.

Vogel, T. 'Ashton gives underwhelming performance', European Voice, 11 January

Wood, D. and Peake, J. (1998) 'The dynamics of foreign policy agenda setting', American Political Science Review 92(1): 173-84. 